\title{
KRITIKÁK
}

DEÁKY ZITA

\section{Történeti közelítések a beásokhoz}

\author{
Nagy Pál: Beás cigányok a Kárpát-medencében (Historikus metsze- \\ tek a 18-19. századból). Gypsy Studies - Cigány Tanulmányok (43.) \\ Pécs: PTE BTK NTI Romológia és Nevelésszociológiai Tanszék, \\ 2019. 186 oldal
}

Nagy Pál lassan harminc éve kutatja a cigányok történetét, és keményen kitart amellett a véleménye mellett, hogy egy adott közösség vagy csoport megismeréséhez szükségesek a minél szélesebb körü történeti ismeretek, és a jelen társadalmi kérdésekre is csak történetileg, az összefüggések rendszerében válaszolhatunk.

Nagy Pál mögött jelentős kutatói munka áll, felelőse egy hatalmas cigány történeti, néprajzi könyvészeti, adattári gyüjteménynek, amelynek méltó helyet keres, hogy az megőrizhető, gyarapítható és kutatható legyen. Nem volt könnyü szakmai útja, és nemcsak a téma gyakran átpolitizált és érzékeny volta miatt, hanem személyisége miatt is, amely kérlelhetetlenül a tényeket tartotta szem elött, és mindenkitől racionális, a tudományt szolgáló, világos szakmai döntéseket szorgalmazott.

A cigány téma iránt érdeklődők vagy azt kutatók között ismert, hogy Nagy Pál történeti forráskiadványaival új utat nyitott a cigányok történeti kutatásában. Ez a könyve is például a Gypsy Studies - Cigány tanulmányok sorozatban jelent meg, a sorozat 43 kötetéből négy az ő könyve.

Szinte minden munkája vitát váltott ki, ugyanis történeti kutatásai, adatai és forrásfeltárásai alapján újra és újra felveti, vagy rá is mutat a cigánykutatások általános módszertani problémáira és kérdéseire, és a jelen romológiai, szociológiai és kulturális antropológiai kutatások történeti perspektíváját hiányolja, továbbá ennek a véleményének markásan hangot is ad.

Már a húsz évvel ezelőtt megjelent, a Cigányperek Magyarországon 1796-1847 címü könyvében is szinte ugyanazt fogalmazta meg, mint a jelenlegi munkájában, egyúttal kijelölte saját magának kutatói feladatát is: „,...bebizonyítsam, a magyarországi cigányok történetének igen is vannak forrásai”, „,.. a Kárpát-medencei

\footnotetext{
Deáky Zita etnográfus, ELTE Néprajzi Intézet. E-mail: deaky9@gmail.com
} 
cigány népesség múltja ugyanúgy kutatható, mint bármely más etnikumé vagy társadalmi csoporté." A történti kutathatóság bizonyítása mellett majd 25 éve tudatosan szakítani akar azzal a szemlélettel is, hogy a cigányok története nemcsak a gádzsók, a nemcigányok rosszindulatának és elöitéleteinek a története, azaz a források nem értelmezhetőek csupán úgy, mint valamiféle „cigánykép” elöítéletes kifejeződései. Ez a szemlélet és törekvés végigvonul munkásságán, és e véleménye mellett a jelenlegi beásokról szóló könyvében is leteszi a voksot.

Nagyon fontos Nagy Pál forráskritikai attitüdje és kutatói önreflexiója, mert nem előfeltételezésekből indul ki, hanem az adatok alakítják következtetéseit. Meri vállalni a bizonytalanságot, nem akar mindenáron kijelenteni, inkább a forrásokon át vezető utat, az értelmezési lehetőségeket tárja fel. A kik a beások, a kísérlet a beások definíciójának megalkotására típusú mondataival, a forrásokban rejlő adatcserepeket felsorakoztatva indul el lépésről lépésre ezen az úton, amely a kötet egyik fö jellemző módszere. Minden új forráscsoport egyre több szempontot, kérdést vet fel, egyre árnyaltabban kell fogalmazni a vándorlási útvonalak, a nyelv, a névhasználat, a tevékenységformák, az interetnikus kapcsolatok, az őket megnevezők, őket csoportba sorolók szempontjából, és végül izgalmas utat járunk be vele a ki a cigány, ki az oláhcigány, beás, teknős, kanalas, vagy mitől cigány vagy román, magyar kérdések kapcsán.

A könyv szigorúan tudományos alapon, adatokkal igazolva igyekszik egy csoport, jelen esetben a beások történelmét, népi kultúráját egészként, a többi népcsoporttal összefüggésben megközelíteni. A megközelítés szó kulcsfontosságú, hisz a 18-19. századi levéltári források és könyvészeti adatok, leírások rengeteg információt tartalmaznak a személynevekre, csoportmegnevezésre, mesterségre, megélhetési módra, felekezeti hovatartozásra vonatkozóan, de ezek csak közelítenek, egyre közelebb visznek a beások megismeréséhez. A közelítés szó igaz akkor is, ha tudjuk, hogy a Kárpát-medencei beások szisztematikus és átfogó történeti, levéltári kutatását ő kezdte el, és senki ekkora munkát nem végzett el eddig.

Nagy Pál ezt a kötetet eddigi kutatásai összegzésének tekinti azzal, hogy jelzi, még mindig vannak olyan forráscsoportok, amelyek feltárásra várnak. Felhívja a figyelmet arra, hogy regionálisan is aránytalanságok vannak a feldolgozásban, azaz bár összegzést adott közre, további kutatásokra van szükség, amit neki és más társadalomtörténészeknek kell elvégezniük, hogy újabb ismeretekkel, közelítésekkel gazdagítsák és árnyalják a beások történetét. Ilyen például a nyelvi kérdés. Milyen nyelven beszéltek a beások elődei, és ugyanolyan nyelven beszéltek-e mindnyájan a 19. század vége előtti időkben? Nagy Pál itt sem kertel, azaz elismeri, hogy ténylegesen nem tudjuk, csak visszafelé feltételezünk; ez a probléma összefügg a területi kulturális mintákkal, és itt elsősorban Erdélyre utal. Ezzel is megindokolja a további regionális kutatások szükségességét, valamint rámutat a nyelvészeti kutatások fontosságára. 
Nem ez az első kötet a beásokról, de ez a könyv az eddigi munkáknál, az a 18-19. századi levéltári és könyvészeti források és Nagy Pál történeti fejtegetései miatt mondható előrelépésnek. Ugyanis egyértelmüvé és bizonyíthatóvá válik, ami egyébként evidens más etnikai, felekezeti, státuszbeli csoporttal kapcsolatban, hogy a cigányok is a kényszerhelyzetek, a megváltozott gazdasági, társadalmi, közigazgatási, politikai vagy akár természetföldrajzi viszonyok miatt újra és újra foglalkozás- és életmódváltással éltek. Például a túlélési stratégia részeként, vagy csak a jobb megélhetés érdekében akár csoportként is részt vettek a migrációs folyamatokban, és mindez új életstratégiával, foglalkozással, életmóddal, új kapcsolatokkal is járt. Nagy Pál forrásfeltárásai rámutatnak, hogy ezek a folyamatok ugyanúgy, mint más etnikai és felekezeti csoportoknál, a beásoknál is alakították, befolyásolták nyelvhasználatukat, életmódjukat, megélhetésüket, társadalmi szerveződésüket, interetnikus kapcsolataikat, összességében csoportkultúrájukat, és ezzel identitásukat is. Így velük kapcsolatban sem beszélhetünk statikus állapotról, zárványlétröl, hisz ezek a váltások a Kárpát-medencében zajlottak, bár eltérö időben, helyeken és intenzitással, de ők is mindenképpen részévé váltak az összmagyarországi történeti folyamatoknak. Éppen ezért a cigányokról, illetve az egyes cigány csoportokról csak időbeni metszetekben, a migrációs útvonalakat, az életformaváltásokat figyelembe véve, a hosszabb-rövidebb ideig az együtt élö népekkel összevetve, a kulturális változásokat nyomon követve lehet beszélni, és sajátosságaikat értelmezni.

Ugyanakkor a csak rájuk vonatkozó rendeletek, így a 18. században a Mária Terézia- és II. József-féle, a cigányokat érintő rendelkezések és hatósági intézkedések a cigányok egyéni és családi életét alapvetően meghatározták, és sajátos döntésekre kényszerítették őket. Ezeken belül a cigány közösségek megtörésére alkalmazott eszköz volt a gyermekek elvétele, amiröl Nagy Pál más helyen írt bővebben. Ebben a kötetben is megjelenik ez a kérdés, illetve a forrásokban, az iratok egy részében feljegyzésre került, hogy a gyermekek a családdal vagy a nevelőszülönél vannak-e. Ez a tény, ez az egzisztenciális fenyegetettség és kiszolgáltatottág sokkal többet mond el a cigányok aktuális helyzetéröl, akár döntéseik, vándorlásaik és életformaváltásuk motivációjáról, mint amit erről eddig tudtunk. A könyvben erre példa éppen a gyermekelvétel elől Somogy megyébe menekült váradi cigány család története, amelyeknek érdekében a földesúr intézkedik, és nem engedi, hogy a hatóság velük szemben érvényesítse a rendelkezés elöírásait. Egyedi eset a rengeteg gyermekelvételi intézkedés mellett, de árnyalja a képet, és további forrásfeltárásra ösztönöz.

A további kutatások szempontjából is megkerülhetetlenek lesznek a kötetben röviden bemutatott 18-19. századi cigányösszeírások is. Ezek olyan források, amelyek segíthetik a cigányság társadalomtörténeti, történeti-néprajzi kutatásait és az értelmezéseket, épp ezért szisztematikus feldolgozásukat el kell végezni. Etnográfiai szempontból különösen az 1773-as 12 rovatos és az 1780-as 37 rovatos összeírás érdekes, tulajdonképpen egy néprajzi gyűjtőív kérdéssorait tartalmazzák. 
A kitöltő személy alaposságától, személyiségétől függően ugyan, de ezek a kimutatások, összeírások rendkívül fontosak lehetnek az adott nyelvi, foglalkozási vagy lokális csoport szempontjából, akár teljes esetleírások is kikerekedhetnek belőlük. A Helytartótanács ebben az időszakban számos más témában is rendelt el hasonló típusú összeírást, például a bábákról, a járványhelyzetről, a megyei, járási egészségügyi viszonyokról, amelyekhez szintén kitöltendő rovatokat, kérdéseket határozott meg. Az általam átnézett 18-19. századi, helytartótanácsi egészségügyi jelentésekben, összeírásokban cigányokra vonatkozó feljegyzéssel nem találkoztam, ezért is nagyon fontosnak tartom a kötetben röviden bemutatott és feltárásra váró cigányösszeírásokat.

Nagy Pál ebben a könyvében is egyértelmüen kiáll a történeti kutatások fontossága mellett, és közben markásan fogalmazza meg véleményét, miszerint a mai cigány kutatások a jelenbeli tapasztalatokat, állapotokat vetítik vissza, szerinte tények ismerete nélkül következtetnek, forrásokat és forráscsoportokat pedig figyelembe sem vesznek (40.). Másrészt Nagy Pál korábbi kutatásaiban és e jelenlegi könyvben is megkérdőjelezi az áldozat- és üldöztetéstörténeti perspektívát. Nem zárványban élö, elszigetelt és társadalmon kívüli csoportnak tekinti a cigányokat, és nem ebböl az alapállásból akarja a cigány csoportok, jelen esetben a beások történetét megalkotni, hanem mint minden más népcsoport esetében, a Kárpát-medencei, tágabban az európai történeti folyamatokba helyezi őket, és ott követi nyomon az együttélés formáit, a csoportalkotás dinamikáját, a kulturális kölcsönhatások jellegét és jeleit. Ez lehetővé teszi a jelenből kiindulva a történeti rétegek feltárását, a történeti folyamatok áttekintését és reálisabb értelmezését.

Teszi ezt azzal együtt, hogy pontosan ismeri a cigányokkal szembeni elöítéletek kialakulásának gyökereit, a vádakat, így az 1782. évi Hont vármegyei kemencei bűnpert, ő maga pedig feldolgozta a szepsi cigányok 1929. évi kassai emberevési törvényszéki perét. Mindkét per igaztalan voltuk ellenére is felerősítette a cigányokkal szembeni ellenérzéseket, az elöítéleteket és a kirekesztési tendenciákat. Mindkét nagy per extrémnek tekinthető, amelyek azonban hatalmas visszhangot váltottak ki, és komoly, igen tragikus következményekkel jártak a cigányokra, és nemcsak a perben érintett és elítélt cigány emberekre nézve. Ugyanakkor a többi, cigánypereket feltáró munkájában Nagy Pál azt is bizonyítja, hogy nem volt a cigányokkal szemben jogi elfogultság, és a cigányok nem követtek el több bünt, mint más perifériára szorult emberek. Ugyanakkor nem kerüli meg a hatalom, a társadalom felelösségének kérdését, így például a jelenlegi könyvben is megjelennek a nevelőszülői rendszer anomáliái és a tragikus életsorsok, de valóban nem erre helyezi a hangsúlyt az értelmezésben.

Nagy Pál vitát vált ki azzal is, hogy a szociológiai és a kulturális antropológiai kutatásokat, azok magyarázatait és elemzéseit nem igazolja történeti forrásokkal, és ahogy arra a legutóbbi írásában is utal, úgy véli, azoknak aktuálpolitikai kapcsolódásai vannak. Sőt hangsúlyozza, hogy a cigány csoportok jelenlegi kultúrája, 
mai szociális és társadalmi problémái történeti folyamatok eredményei, nem pedig egy, a többségi társadalom kirekesztése miatt évszázadok óta megmerevedett statikus állapotról van szó, és nem lehet mindent csak a kirekesztéssel megmagyarázni. Ezzel a megközelítéssel és szemlélettel egyébként nincs egyedül. Thomas Acton szimbiózisteóriája elutasítja az üldözéstörténet kizárólagosságát; az együttélés megközelítésének elméleti alapját adja, és ez Nagy Pál számára is irányt mutató. Azaz, és ez ebben a könyvében is hangsúlyos, ha ebből az aspektusból nézzük, akkor a cigányok és más csoportok közös múltja nem folyamatos szembenállás, sőt, erősebb eleme az összetartozás és az együttélés, amelynek része a folyamatos változás. És ôt idézve: az együttélés modelljét minden időszakban a gazdasági, társadalmi, politikai-jogi, valamint a morális-értékrendi feltételek komplexitása határozza meg. Ebben a könyvében egyértelmủen rámutat arra, hogy a 18. századra kialakultak azok az együttélési modellek a cigányok és nem cigányok között, amelyek lehetővé tették, hogy a cigányok egy része, a beások nagy része is, nemcsak letelepedett, hanem betagozódott a feudális rendbe, a falusi közösségekbe. Megélhetési módjaikban alkalmazkodtak a paraszti társadalom igényeihez, a céhes ipar árnyékában újra és újra megtalálták a helyüket, és nemcsak gazdasági kapcsolatok, hanem több szintü együttmüködések alakultak ki, sőt családi, házassági kapcsolatokra, etnikai átjárásokra is sor került. Azaz Nagy Pál forrásai segítségével kiemeli a beásokat a primitív, iskolázatlan, elzárt erdőlakó sablonból azzal együtt, hogy voltak ilyen közösségek is, de tévút ezt a beások összességére kiterjeszteni, csoportkultúra általános vonásaként értelmezni. Másrészt kiderül az is, hogy a csoporttól független egyéni stratégiák is éltek, amik a nevek és mesterségek összevetésében jól látszanak. Például Kalányos nevü ember lehetett varga, kovács vagy éppen muzsikus is, mert ez segítette a megélhetésben.

Nagyon fontos megállapításnak tekinthetjük a források alapján, hogy a családok egy része önállóan keresett magának helyet, vagyis a kompániás mendikációs stratégia és letelepedés mellett családi útkeresések is voltak. Erre példa Öcsény, ahova a 19. században a beás családok mind-mind más időpontban érkeztek, és nem együtt csoportosan.

Minden társadalomtudománynak szüksége van az egyre mélyebb és szélesebb körü történeti forrásfeltárásokra, ezek segítségével a történeti kontextusok feltárására. Nagy Pállal lehet és kell vitatkozni, mert bár a történeti forrásokra alapozva, kérlelhetetlen logikát és tényszerüséget követ, ugyanakkor az értelmezésekben lehetnek különbségek és eltérések. 